\title{
CHARACTERISTICS OF APS AND VPS PLASMA SPRAY PROCESSES
}

\author{
Mihajlo R. Mrdak \\ Research and Development Center IMTEL, \\ Communications a.d., Belgrade \\ e-mail: miki@imtelkom.ac.rs
}

DOI: 10.5937/vojtehg63-7064

FIELD: Chemical Technology

ARTICLE TYPE: Professional Paper

ARTICLE LANGUAGE: English

\section{Summary:}

Plasma is an electrically conductive gas containing ions, electrons and neutral molecules. This state of matter is created by an electrical discharge and can be maintained at steady state by introducing alternating or direct current. The paper describes the structure of plasma, the thermodynamic characteristics and a method of creating plasma that allow the application of plasma as a source of energy for plasma spray processes. In general, all existing materials in a form of powder may be deposited by plasma coating on the surfaces of various materials. At high temperatures, powder material particles are introduced into a conductive plasma gas, melting and accelerating to the substrate to form coatings. The wide use of plasma spray coatings in all industrial areas is of particular importance, because different combinations of surface layers can significantly increase the resistance of machine parts to: wear, abrasion, erosion, cavitation, corrosion and fatigue resistance at low and elevated temperatures with increased resource and reliability of the parts in service.

Key words: resistivity, powders, plasma gas, conductivity, coatings.

\footnotetext{
* Acknowledgement: The author is thankful for the financial support from the Ministry of Education and Science of the Republic of Serbia (national projects OI 174004, TR 34016).
} 


\section{Introduction}

Plasma is an electrically conductive gas consisting of ions, electrons and neutral molecules. The state and structure of plasma have been studied for yearsby physicists and chemists, while engineers have used plasma in applications ranging from neon lights to thermonuclear fusion. Thermal plasmas are increasingly used for the dissociation of raw materials such as carbonates, oxides, sulfides, and various polymetallic ores (Dembovsky, 1985). Remelting alloys by plasma with high melting temperatures and plasma treatment using pure argon or helium gas have proven to be useful in metal industry. As Dembovsky pointed out, plasma is possible to be used for blending a vast range of materials at pressures between $10^{2}$ and $10^{7} \mathrm{~Pa}$ (Dembovsky, 1985). Spraying plasma is gaseous plasma and can be considered as equilibrium or thermal plasma. The development of the plasma spray process is a result of the attempt to increase the temperature level above that of an oxy-acetylene flame. The main reason for switching from conventional methods of deposition to plasma jet deposition is to increase the temperature level and to control the jet atmosphere. The plasma jet allows the selection of inert or non-reactive gases for the medium so that the chemical reaction of oxidation can be controlled during powder deposition. Temperatures which can be obtained with commercial plasma equipment are above melting and evaporation temperatures of developed materials. Thermal plasma or plasma spraying is a technological process that takes place at atmospheric pressure (APS) or at low pressure (VPS or LPPS). Plasma spray processes have found wide applications in all industrial areas, as described in the published works of authors (Mrdak, et al., 2013, pp.559567), (Mrdak, 2013, pp.68-88), (Mrdak, 2013, pp.26-47), (Vencl, et al., 2009, pp.398-405), (Vencl, et al., 2011, pp.1281-1288). Different combinations of surface layers significantly increase the resistance of the working parts to: wear, abrasion, erosion, cavitation, corrosion and fatigue resistance at low and elevated temperatures. An important place among the twenty-first century technologies that will be intensively developed is occupied by plasma spray processes owing to the development of nano materials that form the basis for the development of many technologies. Plasma spraying is one of the surface treatment technologies and, with other technological processes, it forms an area known as surface engineering. Today, plasma spray is used in mass production as well as in the laboratory studies of new nano materials for future technologies (Herman, 1988, pp.13-21).

The aim of this study was to describe the structure of plasma, its thermodynamic properties and the way it is created, which enables it to be used as an energy source for plasma spray processes (APS and 
VPS), in order to protect the surface of the base material from wear, abrasion, erosion, cavitation, corrosion and fatigue resistance at low and elevated temperatures with increased resource and reliability of the parts in service.

\section{The structure of plasma and its thermodynamic characteristics}

In order to understand the plasma spraying process, first of all it is necessary to know the structure of plasma. Scientists used the name 'plasma' to describe vapor materials raised to a higher energy level. Heated gases follow the classical laws of physics and thermodynamics. However, plasma does not follow the classical laws of physics and, therefore, it is considered the fourth physical state of matter. In order to explain plasma, we must clarify the state changes occurring in atoms and molecules. Figure 1 illustrates a neutral atom $\mathrm{He}$. This atom has a nucleus with two electric charges and is neutral when it is in an excited state. Electrons circle around the nucleus. Each electron has the electric charge -1 . If enough energy is introduced into the atom, it will arouse the atom and at least one electron will be out of its orbit as shown in Figure 1. The amount of energy required to remove an electron from its orbit is called ionization energy.

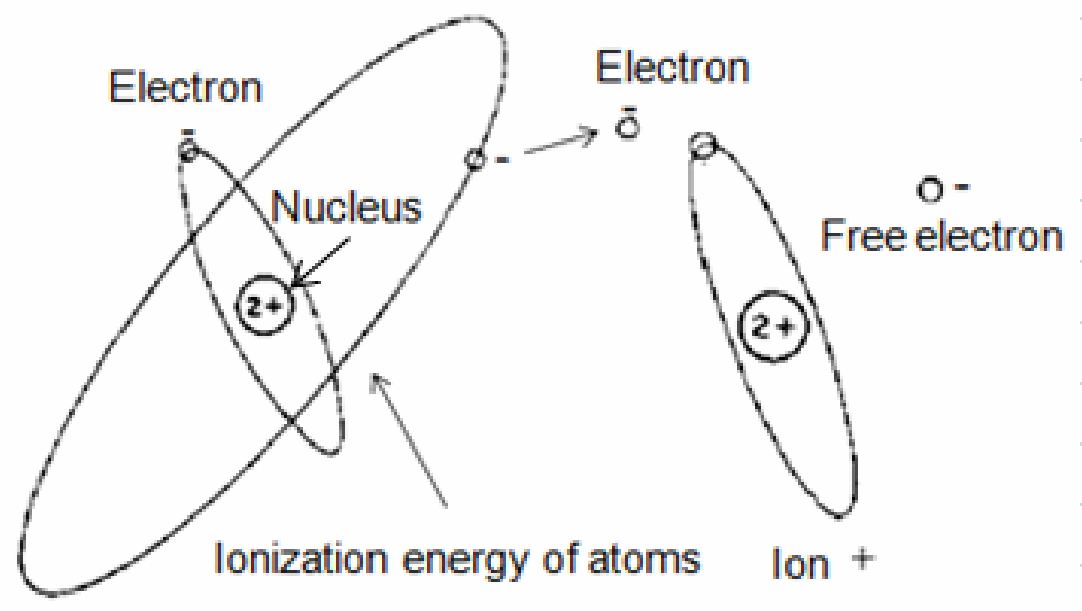

Figure 1 - A neutral atom of helium and an ionized helium atom Slika 1 - Neutralan atom helijuma i jonizovan atom helijuma Puc. 1 - Нейтральный атом гелия и ионизированный атом гелия 
Excited atoms result in two particles. One of the particles is an ionized atom, and the other particle is a free electron. The ionized atom has the electric charge +1 , and the free electron has the electric charge -1 . A molecule which is a fusion of two or more neutral atoms can be considered as one particle. Figure 2 shows the different types of particles. To the left, two atoms bonded together in a molecule are shown. These molecules are gases such as $\mathrm{N}_{2}$ and $\mathrm{H}_{2}$, formed of two atoms and therefore referred to as diatomic gases. To the right, there is an atom representing gases such as Ar or He that are called monatomic gases. It also represents one atom of a dissociated molecule of nitrogen or hydrogen. The labels for the ion and the electron are shown on the right-hand side of the figure. Figure 3 shows four molecules which represent a diatomic gas. If enough energy is introduced, molecules break down into atoms as indicated by the arrows. lgnoring the arrows, Figure 4 shows the separated atoms which may present a monatomic gas such as $\mathrm{Ar}$ or $\mathrm{He}$ or a dissociated diatomic gas $\mathrm{N}_{2}$ or $\mathrm{H}_{2}$, as previously discussed.

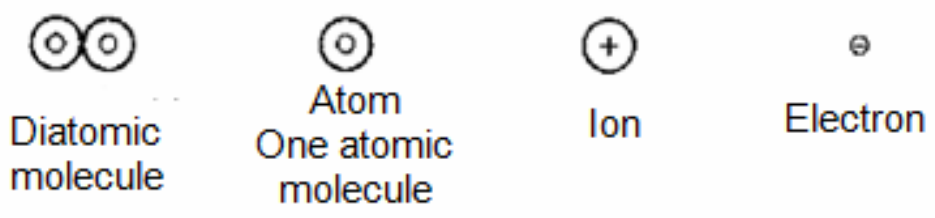

Figure 2 - Molecules and atoms of plasma gases Slika 2 - Molekuli i atomi plazma gasova

Puc. 2 - Молекулы и атомы в плазменном газе<smiles></smiles>

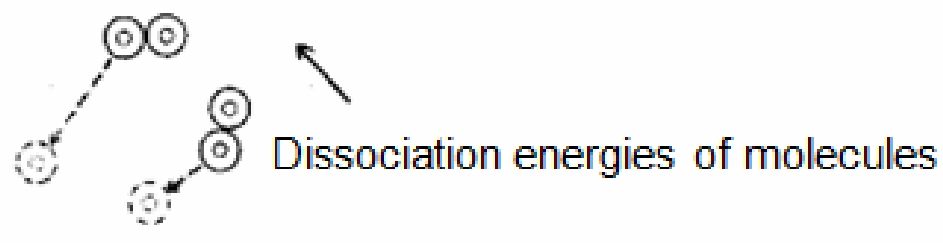

Figure 3 - Dissociation of diatomic gases Slika 3 - Disocijacija dvoatomskih gasova Puc. 3 - Диссоциация двухатомных газов 


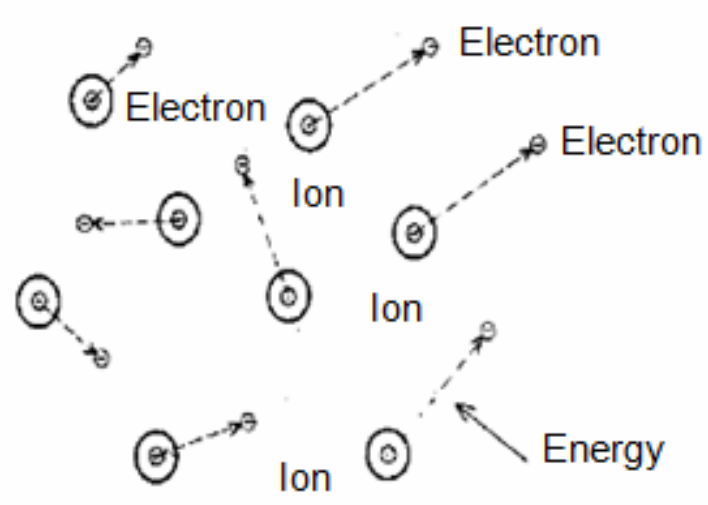

Figure 4 - Ionization of atoms obtained by the dissociation of a gas Slika 4 - Jonizacija atoma dobijenih disocijacijom gasa

Puc. 4 - Ионизация атомов, образованная при диссоциации газа

By further introducing the energy into atoms, at least one electron from each atom is moves out of its orbit, as shown by arrows. If all the electrons leave their atoms, complete ionization is achieved - the state of stars with a temperature close to 100 million ${ }^{\circ} \mathrm{C}$. In the plasma spray process, partial ionization is obtained and the operating temperatures up to $30,000^{\circ} \mathrm{C}$. It should be noted that plasma is electroneutral as a whole, since it has the same number of positive and negative electric charges. The advantage of plasma over ordinary gases is that it has a higher temperature and better heat transfer. Figure 5 shows the dependence of the enthalpy on the plasma temperature for different gas types at the atmospheric pressure (Gajić, et al., 1996, pp.448-451). For $\mathrm{N}_{2}$, the gas curve has a very gentle slope. In this part of the diagram, the temperature is changing rapidly with the amount of heat input. When it reaches the level of dissociation, the line moves vertically showing great energy absorption with a slight change in temperature. This is the dissociation area where the $\mathrm{N}_{2}$ molecule breaks down into atoms. With the further heating of a now atomic gas, the curve flattens out, but soon begins to climb when the ionization zone is reached. It is important to notice that diatomic gases, as a rule, have more similar curve slopes than monatomic gases. Therefore, from the standpoint of enthalpy changes, diatomic gases are superior to monatomic gases. Plasma has high electrical conductivity which is connected to very high temperatures. The electrical conductivity of plasma is to a large extent conditioned by the degree of ionization, i.e. by electron mobility, which is about 100 times higher than that of ions. Ionization can be partial or multistage. The energy of gas ionization is from 10 to $50 \mathrm{eV}$, and that of dissociation is from 4 to $10 \mathrm{eV}$. 


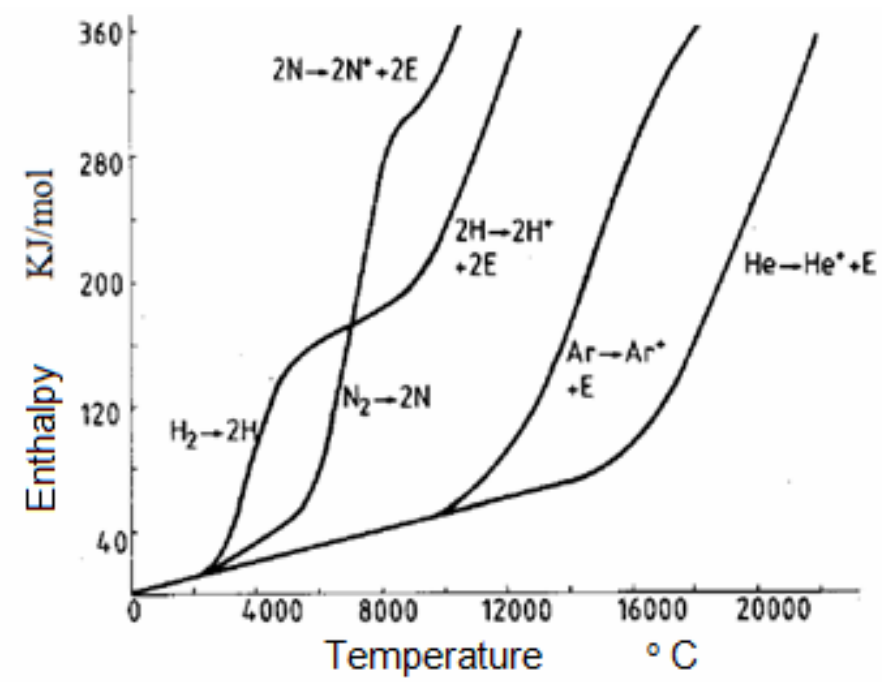

Figure 5 - Dependence of the enthalpy on the temperature of plasma gases (Gajić, et al., 1996, pp.448-451)

Slika 5 - Zavisnost entalpije od tempetrature plazma gasova (Gajić, et al., 1996, pp.448-451)

Puc. 5 - Зависимость энтальпии от температуры плазменных газов (Гаич и др., 1996, стр.448-451)

Gas dissociation and ionizationoccur during a certain period of time and the energies of ionization and dissociation recombine as shown for the $\mathrm{N}_{2}$ gas.

$$
\begin{array}{lll}
\mathrm{N}^{* * *} \leftrightarrow \mathrm{N}^{* *} & +\mathrm{e} 47.0 \mathrm{eV} & \\
\mathrm{N}^{* *} \leftrightarrow \mathrm{N} & +\mathrm{e} 29.0 \mathrm{eV} & \text { Ionization degrees } \\
\rightarrow & \mathrm{N}^{*} \leftrightarrow \mathrm{N} & +\mathrm{e} 14.5 \mathrm{eV} \leftarrow \\
\mathrm{N}+\mathrm{N} \leftrightarrow \mathrm{N}_{2} \quad 9.7 \mathrm{eV} &
\end{array}
$$

For monatomic gases, there is no dissociation or recombination, which, for diatomic gases, take place at lower temperatures. Because of this, for the same power supply, the Ar and He plasma jets are shorter than the $\mathrm{N}_{2}$ and $\mathrm{H}_{2}$ plasma jets. Thermal conductivities of plasma jets are complex functions and they have different values at different temperatures. Table 1 shows the comparative values of the specific heat and the thermal conductivity of individual gases. The shown values of the specific heat and the thermal conductivity of gases are proven at a temperature of $20 \mathrm{C}^{\circ}$ and a pressure of 1013 mbar (Teaching plasma spraying, Introducing plasma spray techniques, Plasma - Technik 5610, Wohlen, Switzerland). 
Table 1 - Values of the specific heat and the thermal conductivity of individual gases Tabela 1 - Vrednosti specifične toplote i toplotne provodljivosti za pojedine gasove Таблица 1 - Значения теплоемкости и теплопроводности некоторых газов

\begin{tabular}{|c|c|c|}
\hline Gas & $\begin{array}{c}\text { Specific heat } \\
(\mathrm{J} / \mathrm{kg} \mathrm{K})\end{array}$ & $\begin{array}{c}\text { Thermal conductivity } \\
(\mathrm{W} /(\mathrm{m} \mathrm{K})\end{array}$ \\
\hline Argon & 0.122 & $14.9 \times 10^{-3}$ \\
\hline Helium & 1.26 & $1130.0 \times 10^{-3}$ \\
\hline Air & 0.24 & $22.1 \times 10^{-3}$ \\
\hline Oxygen & 0.219 & $22.5 \times 10^{-3}$ \\
\hline Nitrogen & 0.248 & $22.0 \times 10^{-3}$ \\
\hline Hydrogen & 3.42 & $157.0 \times 10^{-3}$ \\
\hline
\end{tabular}

The easiest method of forming plasma is to use gases $\mathrm{Ar}, \mathrm{He}, \mathrm{H}_{2}, \mathrm{~N}_{2}$ or their mixtures. Ar has the highest priority because it is easily ionized. The enthalpies of $\mathrm{Ar}$ and $\mathrm{He}$ are much lower than those of diatomic gases, as shown in Figure 5. On the other hand, the temperatures of inert gases are much higher than those of $\mathrm{N}_{2}$ and $\mathrm{H}_{2}$ at the same enthalpy. Plasma is different from the flame of combustion gases due to the fact that the chemical reaction of combustion gases occurs at a distance of 100 to 200 $\mathrm{mm}$ and has a lower temperature than plasma. Plasma is a bright ionized gas in which there is no combustion and has a high temperature and a rapid temperature drop after leaving the nozzle.

\section{The plasma spray processes}

Depending on the surrounding environment, there were developed the atmospheric plasma spray - APS and the vacuum plasma spray VPS processes that still uses the name of the LPPS (Low preassure plasma deposition). The process selection is largely determined by the properties of deposited coatings as well as by their behavior in service as described in the works of the authors (Mrdak, 2013, pp.7-25), (Mrdak, 2013, pp.26-47), (Mrdak, 2014, pp.7-22).

The APS process is the simplest to perform and has a limited range of use due to the incorporation of substantial amounts of air into the plasma jet. The air cools and slows down the plasma, while a special problem is the oxidation of particles, which results in an increased content of oxidation products in the deposited layer (Mrdak, 2010, pp.5-16), (Mrdak, 2012, pp.182-201), (Vencl, et al., 2010, pp.591604). Plasma spraying is done using a plasma gun from which emerge 
focused plasma particles of inert gas at a rate of 240 to $600 \mathrm{~m} / \mathrm{s}$ and a temperature of the jet from 4,500 to $20,000^{\circ} \mathrm{C}$. The plasma jet leaving the nozzle is not homogeneous due to the large differences in the temperature and velocity of plasma particles (Vardelle, et al., 1983, p.88). The plasma core zone has a relatively constant temperature of $12500-12000{ }^{\circ} \mathrm{C}$ and extends to only $10-12 \mathrm{~mm}$ from the nozzle. The second zone is a transitional area where plasma temperature rapidly decreases to $3000{ }^{\circ} \mathrm{C}$, reaching a length of about $100 \mathrm{~mm}$ from the nozzle. The third zone is an area where there is intense plasma mixing with the surrounding air, which leads to a drop in temperature and in velocity of plasma particles. Temperature and velocity of plasma particles, as well as the length of the plasma arc depend on the type of primary and secondary gas velocity and pressure of a gas mixture, power arc discharge and operating pressure (Smith, et al., 1988, p.25). The quality of the plasma jet is highly variable during the deposition itself, because it is not a stationary system. The length of the plasma jet changes in cycles with a frequency of $300 \mathrm{~Hz}$. This is explained by the instability of the arc between the cathode and the anode (Kieschke, et al., 1991, p.25). The quality of the deposited layers depends on: the characteristics of the used powder; reaction between the plasma and the powder; the reaction between the plasma and the impact of the environment as well as on the substrate. Powders used for deposition are characterized by their chemical composition, density, melting temperature, grain size, grain size distribution, particle shape, behavior when moving through plasma, purity, etc. The process parameters must be set in such a way that the optimal effect of melting the particular powder in plasma is achieved and molten powder particles are transported with optimal speed to the substrate surface. The most important parameters that must be controlled are the plasma power, the gas flow and the rate of powder addition into plasma, which is explained in the works of the authors (Mrdak, 2014, pp.7-22), (Mrdak, 2014, pp.726), (Mrdak, 2014, pp.7-25). An efficient addition of the powder into the plasma jet has always been a problem solved by the means of: different constructions of the powder dispenser, variation in the diameter of powder feed channels, varying the type and pressure of the gas transporting the powder and varying the position of the powder feed channels. The powder feed channels can be placed in front of the nozzle to the position above or below at a certain angle and within the plasma gun nozzle, all of which gives a large number of possible combinations. Injected powder particles in the plasma jet partially or completely melt depending on the location of injection powder, amount of time spent in plasma, and the size and range of particles. The adjustment and choice of deposition parameters is determined by 
analyzing the shape of particles and the degree of fusion after passing through plasma, using the methods of metallographic analyses of the microstructure of the deposited layers, microhardness, and other analyses. The process of coat depositing consists of surface preparation prior to deposition processes and deposition processes on prepared surfaces. The preparation of the substrate surface is one of the most important factors that influence the quality of the bond between the metallic substrate and the deposited coating. Surface preparation is carried out in order to clean the oxide layer from the surface of the metallic substrate, making it reactive with the coating in order to increase the surface area between the metal substrate and the coating. Figure 7 shows the Plasmadyne company equipment, used for the plasma deposition of coatings at atmospheric pressure. It consists of: the space for supplying electricity, water and gas; noise protection cabin type TB - KA; device for manipulation, robot STAR - REIS - V with a rotary table PD10; control board 3600; sources of power supply 2 x $40 \mathrm{KW}$ type PS61S; plasma gun type SG - 100; powder feeder model 1251; high-frequency arc starter for the closed system of water cooling of the plasma gun with a pressure control in the installation (Mrdak, 2010, pp.5-16). In the APS process, inert gas Ar is introduced through the gas injector opening between the cathode and the anode. To initiate plasma, between the electrodes there is direct current which generates an electrical impulse causing the break-through in liquid gas. After establishing an electric arc - arc plasma, secondary gas $\left(\mathrm{He}, \mathrm{H}_{2}\right.$ or $\left.\mathrm{N}_{2}\right)$, which ionizes, is introduced through the gas injector opening. Due to the nature of the geometry of the electrodes as well as technical gases ( in the plasma state now) hot and partially conductive gas passes through the circular aperture of the anode. In the thus formed plasma jet, powder is introducedusing a carrier gas. Powder particles accelerate and melt rapidly, being deposited on the substrate. The energy of the plasma jet can be adjusted for each type of powder, taking into account: melting temperature, thermal conductivity, and the shape, size and distribution of particles. In addition to the powder characteristics, there are the conditions of powder injection into the plasma jet. They are the powder injection location and the angle relative to the jet direction and the powder injection rate. The flow of the carrier gas is adjusted for each type of powder based on the average particle size of the powder, its density and the density of the plasma jet, so that the powder particles are injected into the plasma jet axis with the highest temperature. The flow of the secondary gas, amperage, voltage and the distanceof the plasma jet can be adjusted for each type of powder, so that the particles which are deposited have the optimal kinetic energy and the optimal melting degree. 

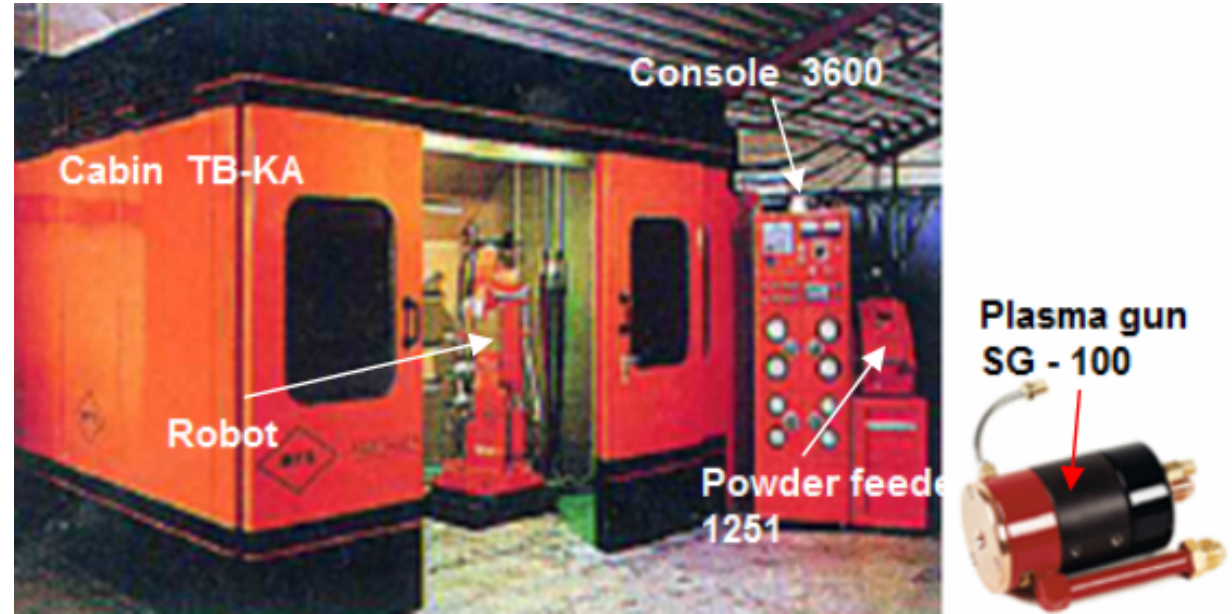

Figure 7 - APS equipment for plasma powder deposition at atmospheric pressure (Mrdak, 2010, pp.5-16)

Slika 7 - APS oprema za depoziciju praha plazmom na atmosferskom pritisku (Mrdak, 2010, pp.5-16)

Puc. 7 - АПН Установка для нанесения порошкового плазменного покрытия под атмосфрерном давлением (Мрдак, 2010, стр.5-16)

The development of the VPS technology has led to significant improvements in the quality of coatings compared to coatings produced at atmospheric pressure. VPS is a relatively new technology in which molten powder particles from 10 to $100 \mu \mathrm{m}$ in size accelerate to the substrate, where they become flat and solid. VPS coatings generally show a higher density than coatings deposited by the atmospheric plasma spray process, where coatings have lamellae composed of columnar grains. Particles solidify with a very fast cooling rate from $\sim 10^{4}$ to $10^{8} \circ \mathrm{C} / \mathrm{sec}$. The operating vacuum is in the range from 30 to 200 mbar, which enables a deposition of coatings with a thickness of 20 to 2 $\mathrm{mm}$. The pressure lower than atmospheric conditions increases a length of the plasma jet from 50 to $600 \mathrm{~mm}$ and a diameter from 10 to $40 \mathrm{~mm}$. The velocities and temperature values of particles in the plasma jet are more uniform, which allows the production of homogeneous coatings of uniform thickness on parts with complex geometries (Gindrat, et al., 2002, pp.459-464). In the process of deposition at atmospheric pressure, the plasma jet temperature rapidly decreases with distance. At low pressure, the temperature of the plasma jet gradually decreases as a function of pressure. For the same distance from the nozzle,a drop in temperature is smaller as the pressure is lower. Figure 8 shows the effect of pressure on the temperature of the plasma jet (Nikoll, 1984). 


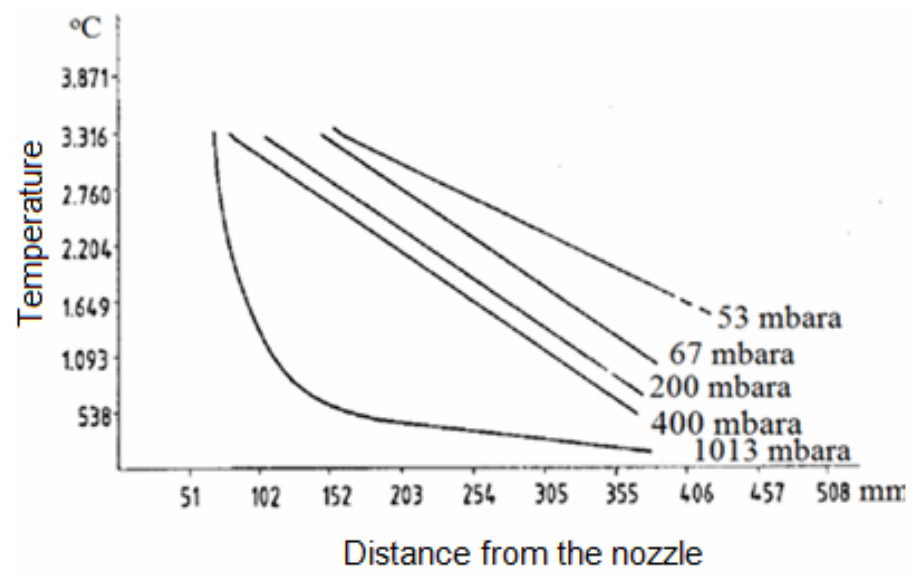

Figure 8 - Effect of operating pressure on the temperature of plasma jets Slika 8 - Uticaj radnog pritiska na temperature mlazeva plazmi

Puc. 8 - Воздействие давления на температуру плазменной струи

The VPS process is performed at a low pressure of Ar in very clear conditions and with the use of the transferred arc for cleaning and preheating the substrate. $\mathrm{Ar}, \mathrm{He}, \mathrm{H}_{2}, \mathrm{~N}_{2}$, and gas mixtures of high purity can be used as plasma gases. Figure 9 shows the VPS system of the Plasma Technik AG company, which possesses an A - 2000 console and an F4 plasma gun. The VPS system is designed to protect the aircraft parts exposed to a combination of excessive oxidation and hot corrosion (Mrdak, 2013, pp.26-47). The powder deposition is usually performed with a mixture of $\mathrm{Ar}-\mathrm{H}_{2}$ plasma gases at low pressure in the vacuum. In the vacuum chamber there are: a rotary table, planetary systems with 48 tools, a six-axis robot and an artificial hand. The manipulation system is designed to simultaneously rotate the tool and the operating parts around their axes.
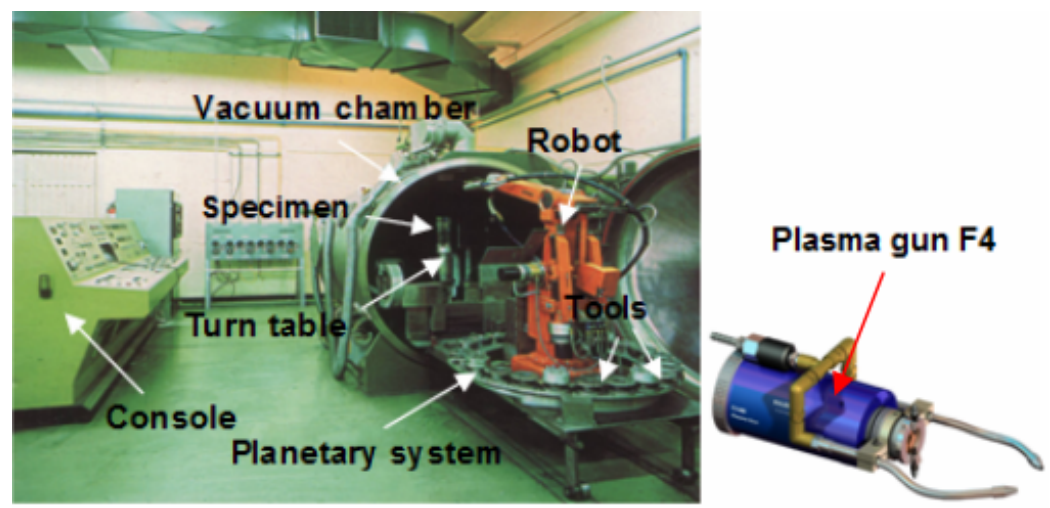

Figure 9 - Vacuum plasma spray system (Mrdak, 2013, pp.26-47)

Slika 9 - Vakuum plazma sprej sistem (Mrdak, 2013, pp.26-47)

Puc. 9 - Система вакуумного плазменного нанесения (Мрдак, 2013, cmp.26-47) 
This complex movement allows uniform cleaning by the transferred arc and uniform powder depositing over the whole surface of the substrate. All procedures, being the parts of the VPS surface treatment process, must be carried out as quickly as possible. In order to obtain fast chamber vacuuming, a high pumping capacity is required. To achieve a chamber pressure of $1000-0.1$ bar, a time of 5 minutes is necessary. Taking workpieces in and out should be done as quickly as possible after the chamber ventilation. All inside surfaces of the vacuum chamber become protected by plasma gases during the process of VPS protection. Only neutral gas atoms bind to the chamber surfaces due to Vander - Waals forces, which means that there is a possibility to save time on chamber vacuuming after the introduction and removal of workpieces. The choice of plasma gas, the flow rate and the current arc determine the content of the plasma jet energy. The characteristics of the plasma jet inside and outside the gun are influenced by the pressure in the chamber. As the pressure decreases, the plasma jet becomes longer in proportion to the increase in gas velocity. The pressure in the chamber must be maintained constant during deposition. Deposition at a low pressure of 30 to $70 \mathrm{mbar}$ allows the application of the transferred arc and higher velocities of plasma particles. The transferred arc enables the cleaning of the substrate surface and its preheating prior to powder deposition, as well as additional heating during deposition. Figure 10 shows possible lengths of the $\mathrm{Ar} / \mathrm{He}$ plasma jet, depending on the pressure in the vacuum chamber and the applied transferred arc (Kieschke, et al., 1991, pp.25-38).

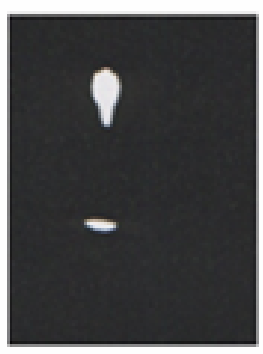

Normal atmosphere

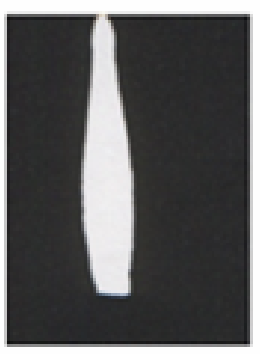

$\mathrm{P}=70 \mathrm{mbar}$

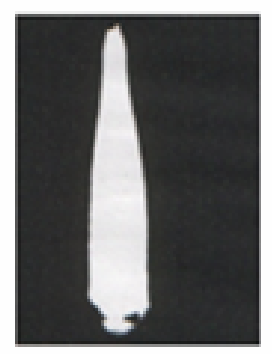

$\mathrm{P}=70 \mathrm{mbar}$ and transferred

Figure 10 - Lengths of $\mathrm{Ar} / \mathrm{He}$ plasma arcs for different atmospheres and transferred arc application

Slika 10 - Dužine mlazeva plazmi $\mathrm{Ar} / \mathrm{He}$ za različite atmosfere i primenu transferovanog luka

Puc. 10 - Длина плазменной струи Ar / Не прямым нагревом при различной температуре 
Figure 11 shows the effect of the transferred arc on the possible length of the $\mathrm{Ar} / \mathrm{H}_{2}$ plasma jet when the deposited powder is CoNiCrAlY (Mrdak, 2013, pp.26-47), (Nikoll, 1984).

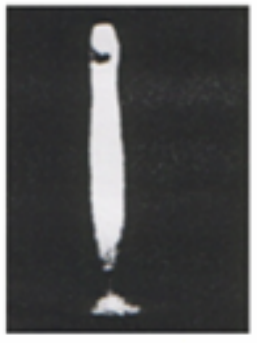

Transferred arc Powder

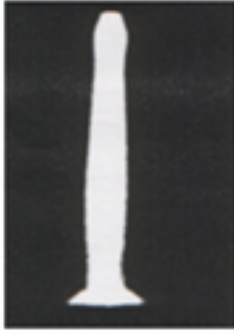

Work piece

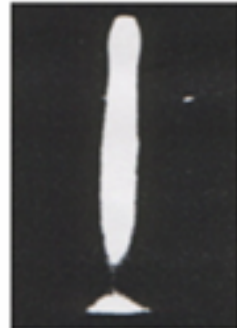

Work piece Work piece + pole - pole

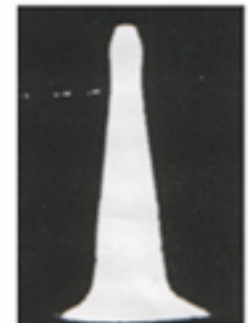

CoNiCrAlY

Figure 11 - Lengths of $\mathrm{Ar} / \mathrm{H}_{2}$ plasma arcs when CoCrAlY powder is deposited with the application of the transferred arc

Slika 11 - Dužine mlazeva plazmi $\mathrm{Ar} / \mathrm{H}_{2}$ kada se deponuje prah CoCrAlY sa primenom transferovanog luka

Puc. 11 - Длина плазменной струи $\mathrm{Ar} / \mathrm{H}_{2}$, при нанесении порошкового вещества CoCrAlY прямым нагревом

Different levels of pressure for the transferred arc can be used, depending on the characteristics of the base material and the powder. To form a plasma jet with optimum characteristics, the gas flow rate may vary between 1.5 and $20 \mathrm{~m}^{3}$ depending on the type of powder being deposited. The deposition of coatings on substrates is performed as follows. Working parts are mounted in the supporting tools that are on the planetary system which rotates around its axis. After the mounting of the working parts, the vacuum chamber is closed. The entire system is automated and programmed on the robot's microprocessor unit. All process parameters are entered into the program. The process of chamber vacuuming, the flow of plasma gases, the substrate cleaning, the powder flow, deposition, the substrate cooling and the vacuum chamber ventilation are fully synchronized by the program. In the VPS chamber, an artificial hand on the other side of the opening of the chamber and which cannot be seen in the photograph, receives the tools with a working part from the planetary system and sets it on the rotary table. After the mounting of the tools with the working part, the chamber is vacuumed where a pressure of $10^{-3} \mathrm{mbar}$ is achieved in $5 \mathrm{~min}$. When the vacuuming process ends, $\mathrm{Ar}$ is introduced into the chamber through the anode to a pressure of 25 mbar. At this pressure, cleaning of work parts surfaces is carried out by the transferred arc. The distance between the plasma gun from the surface of working parts is usually $270 \mathrm{~mm}$. The plasma gun is set to the + pole, and the working part to the - pole. This bond is called direct polarity and it allows the directed ions of $\mathrm{He}$ as a secondary gas to clean the surface of 
the work part at high rate and energy by making the surface reactive. After the cleaning, powder is deposited on the surface of the work part. The secondary plasma gas $\mathrm{H}_{2}$ is added to the primary gas $\mathrm{Ar}$. The pressure in the chamber grows to the level of the operating pressure of 70-120 mbar, depending on the type of powder that is deposited. The constant pressure during the deposition is provided by the vacuum pump. When the operating pressure is reached, powder is introduced into the plasma gun. The deposition rate is constant and does not change during deposition. A coating layer of $0.1 \mathrm{~mm}$ is deposited for 1 min approximately. When the deposition process is completed, the working part is cooled in the chamber to a temperature of $300{ }^{\circ} \mathrm{C}$ with argon flowing from the anode of the F4 plasma gun. The cooled working part with the tool is accepted by the artificial hand and returned to its original position. The planetary system is pivoted by one step to enable the artificial arm to receive another tool with a working part. The powder deposition cycle was repeated until powder is not deposited on all working parts.

\section{Conclusion}

The paper describes the structure of plasma, the method of creating plasma, thermodynamic properties such as enthalpy, temperature, specific heat and thermal conductivity of gases and plasma spray processes at atmospheric pressure and in vacuum at low pressure of inert gas. Plasma spray processes have been developed for the deposition of molten or semi-molten powder particles on the surface of the underlying material on which the deposited particles form a coating.

The advantage of the plasma spray process is the possibility of applying a large number of different materials in the form of powder of various grain and morphology, which are suitable for the formation of coatings in order to protect the surface of the base metal from wear, abrasion, erosion, cavitation, and corrosion resistance to fatigue at low and high temperatures.

Plasma spray processes also allow the modifications of powders, such as the spheroidization of powders with sharp edges, thickening of porous particles, and more recently the formation of nanopowders. The advantage of the process is that molten powder particles with high melting points do not transfer a large amount of heat into the base material and do not violate the basic structure of the material. In the deposition process, it is essential to control the heat transfer from the coating to the substrate, which is a function of the composition of the plasma gas, power supply, and the residence time of particles in the plasma jet.

APS and VPS plasma spray processes have been widely used in the manufacture of new parts in order to protect work surfaces and repair worn parts in the process of repair using appropriate coatings that significantly improve their functionality and increase their service life. 


\section{Literature}

Dembovsky, V. 1985. Plasma Metallurgy.Amsterdam: Elsevier.

Gajić, D., Mrdak, M., \& Gredić, T. 1996. Properties of metal alloy coatings deposited by plasma spraying. . In: 18th Simposium on the Physics of Ionized Gases SPIG'96, Kotor., pp.448-451

Gindrat, M., Dorier, J.L., Hollenstein, C., Loch, M., Refke, A., Salito, A., \& Barbezat, G. 2002. Effect of Specific Operating Conditions on the Properties of LPPS Plasma Jets Expanding at Low Pressure. . In: E. Lugscheider\& C.C. Berndt Eds., Proceedings of the 3rd ITSC. Essen, Germany: DVS-Verlag., pp.459-464

Herman, H. 1988. The Plasma State and its Industrial Utility. . In: 1st PlasmaTechnik-Symposium Lucerne/Switzerland, May 18th to 20th. , pp.13-21

Kieschke, R.R., Roberts, K.A., \& Clyne, T.W. 1991. Instabilities in the vacuum plasma spraying process. Surface and Coatings Technology, 1(46), pp.25-38.

Kieschke, R.R., Roberts, K.A., \& Cyne, T.W. 1991. . Surface and Coatings Technology, 46, p. 25.

Mrdak, M. 2010. Uticaj brzine depozicije praha na mehaničke karakteristike i strukturu APS - NiCr/Al prevlake. Vojnotehnički glasnik/Military Technical Courier, 58(4), pp.5-16.

Mrdak, M. 2012. Plasma deposited layers of nickel-chrome-aluminum-yttrium coatings resistant to oxidation and hot corrosion. Vojnotehnički glasnik/Military Technical Courier, 60(2), pp.182-201.

Mrdak, M. 2013. Characterization of nickel - graphite sealing coatings in the system with the nickel-aluminum coating bonding. Vojnotehnički glasnik/Military Technical Courier, 61(1), pp.68-88.

Mrdak, M. 2013. Structure and properties of plasma sprayed APS - Ni20Al coatings. Vojnotehnički glasnik/Military Technical Courier, 61(2), pp.7-22.

Mrdak, M. 2013. Properties and structure of tungstencarbide - cobalt coatings deposited by the APS - plasma spray process. Vojnotehnički glasnik/Military Technical Courier, 61(3), pp.7-25.

Mrdak, M. 2013. Characterization of vacuum plasma sprayed cobalt-nickelchromium-aluminum-yttrium coatings. Vojnotehnički glasnik/Military Technical Courier, 61(4), pp.26-47.

Mrdak, M., Vencl, A., Nedeljkovic, B., \& Stanković, M. 2013. Influence of plasma spraying parameters on properties of the thermal barrier coatings. Materials Science and Technology, 29(5), pp.559-567.

Mrdak, M. 2014. Characterization of the wear resistant aluminum oxide $40 \%$ titanium diokside coating. Vojnotehnički glasnik/Military Technical Courier, 62(1), pp.7-22.

Mrdak, M. 2014. Influence of a powder feed rate on the properties of the plasma sprayed chromium carbide $25 \%$ nickel chromium coating. Vojnotehnički glasnik/Military Technical Courier, 62(2), pp.7-26.

Mrdak, M. 2014. Effect of helium plasma gas flow rate on the properties of WC-12 wt.\% Co coatings sprayed by atmospheric plasma. Vojnotehnički glasnik/Military Technical Courier, 62(3), pp.7-25.

Nikoll, A.R. 1984. Protective Coatings and Their Processing Thermal Spray. . In: Plasma Technik AG-Switzerland, Course June 24-29,Finland.

Smith, M.F., \& Dykhuizen, R.C. 1988. . Surface and Coatings Technology, 34, p. 25.

Teaching plasma spraying, Introducing plasma spray techniques, Plasma-Technik 5610 . Switzerland: Wohlen. 
Vardelle, M., Vardelle, A., \& Fouchais, P. 1983. . . In: Proc. of 19th Thermal Spray Conf. Dusseldorf. , p. 88

Vencl, A., Mrdak, M., \& Banjac, M. 2009. Correlation of Microstructures and Tribological Properties of Ferrous Coatings Deposited by Atmospheric Plasma Spraying on Al-Si Cast Alloy Substrate. Metallurgical and Materials Transactions A, 40(2), pp.398405. doi:10.1007/s11661-008-9693-0

Vencl, A., Manić, N., Popovic, V., \& Mrdak, M. 2010. Possibility of the abrasive wear resistance determination with scratch tester. Tribology Letters, 37(3), pp.591-604.

Vencl, A., Arostegui, S., Favaro, G., Zivic, F., Mrdak, M., Mitrović, S., \& Popovic, V. 2011. Evaluation of adhesion/cohesion bond strength of the thick plasma spray coatings by scratch testing on coatings cross-sections. Tribology International, 44(11), pp.1281-1288.

\section{СВОЙСТВА АПН И ВПН МЕТОДОВ ПЛАЗМЕННОГО НАПЫЛЕНИЯ}

ОБЛАСТЬ: химические технологии

ВИД СТАТЬИ: профессиональная статья

ЯЗЫК СТАТЬИ: английский

Резюме:

Плазма - ионизированный газ, содержащий электроны и нейтральные молекулы, способный проводить ток. Данное состояние вещества создается с помощью электрического разряда и может подерживаться в стабильном состоянии при применении переменного или постоянного тока.

В статье описаны структура плазмы, ее термодинамические свойства и способы образования, обеспечивающие возможность применения плазмы в качестве энергоносителя в процессе плазменного напыления. В основном, все порошковые вещества могут быть использованы для плазменного напыления покрытий, выполненных из различных материалов.

Высокая температура при введении порошковых веществ в плазму способствует ускорению процесса плавки и формирования частиц продукта, напыляемого на покрытие.

Рекомендуется широкое применение метода плазменного напыления покрытий во всех промышленных отраслях, так как комбинированные слои покрытия способствуют повышению стойкости деталей машиностроения против: абразивного износа, эрозии, кавитации, коррозии, а также отличаются высокой термостойкостью и устойчивостью к усталости под действием давления и ударных нагрузок. При этом значительно повышается ресурс восстанавливаемой детали и надежность в процессе эксплуатации.

Ключевые слова: сопротивление, порошковые вещества, плазменный газ, проводимость, покрытие. 
KARAKTERISTIKE APS I VPS PLAZMA SPREJ PROCESA

OBLAST: hemijske tehnologije

VRSTA ČLANKA: stručni članak

JEZIK ČLANKA: engleski

Sažetak:

Plazma je električno provodljiv gas koji sadrži jone, elektrone i neutralne molekule. Takvo stanje materije stvara se preko električnog pražnjenja i može da se održava u stabilnom stanju uvođenjem naizmenične ili jednosmerne struje. U radu je opisana struktura plazme, termodinamičke karakteristike i način stvaranja plazme koji omogućuju primenu plazme kao izvora energije za plazma sprej procese. Generalno, svi postojeći materijali u obliku praha mogu se plazmom deponovati kao prevlake na podlogama od različitih materijala. U plazma provodljivi gas na visokoj temperaturi uvode se čestice praha materijala koje se tope i ubrzavaju do podloge na kojoj formiraju prevlake. Masovna primena plazma sprej prevlaka u svim industrijskim oblastima je od posebnog značaja, jer se sa različitim kombinacijama površinskih slojeva može znatno povećati otpornost mašinskih delova na: habanje, abraziju, eroziju, kavitaciju, koroziju i otpornost na zamor na niskim i povišenim temperaturama, uz povećani resurs i pouzdanost rada delova u eksploataciji.

Uvod

Plazma je električno provodljiv gas čija se struktura sastoji od jona, elektrona i neutralnih molekula. Stanje $i$ strukturu plazme godinama su proučavali fizičari i hemičari, a inženjeri koristili za primene koje se kreću od neonskog svetla do termonuklearne fuzije. Termalne plazme se sve više koriste za disocijaciju sirovina kao što su karbonati, oksidi, sulfidi i razne polimetalne rude (Dembovsky, 1985). Pretapanje legura plazmom sa visokim temperaturama topljenja i prečišćavanje pomoću čistih plazma gasova argona ili helijuma dokazala se korisnim u industriji metala. Plazma spreing je gasna plazma i može se smatrati kao ravnotežna ili termalna plazma. Razvoj plazma sprej procesa bio je rezultat objektivnog pokušaja da se podigne temperaturni nivo iznad onog kod oksiacetilenskog plamena. Mlaz plazme omogućuje selekciju inertnih ili nereaktivnih gasova za medijum, tako da se hemijska reakcija oksidacije može kontrolisati za vreme depozicije praha. Termalna plazma ili plazma spreing je tehnološki proces koji se odvija na atmosferskom pritisku (APS) ili na niskom pritisku (VPS) ili (LPPS) procesu. Plazma sprej procesi su našli široku primenu u svim industrijskim oblastima, što je opisano u objavljenim radovima autora (Mrdak, et al., 2013, pp.559-567), (Mrdak, 2013, pp.68-88), (Mrdak, 2013, pp.26-47), (Vencl, et al., 2009, pp.398-405), (Vencl, et al., 2011, pp.1281-1288). 
Različitie kombinacije površinskih slojeva znatno povećavaju otpornost radnim delovima na: habanje, abraziju, eroziju, kavitaciju, koroziju i otpornost na zamor na niskim i povišenim temperaturama. Značajno mesto među tehnologijama dvadeset prvog veka koje će se intenzivno razvijati imaju plazma sprej procesi, zahvaljujući razvoju nano materijala koji čine osnov za razvoj mnogih tehnologija. Plazma spreing je jedna od tehnologija obrade površina i sa drugim tehnološkim postupcima čini jednu celinu koja je u svetu poznata pod nazivom inženjerstvo površina. Danas se plazma sprej koristi u masovnoj proizvodnji, ali i u laboratorijskim istraživanjima novih nano materijala za tehnologije budućnosti (Herman, 1988, pp.13-21).

Cilj rada bio je da se opiše struktura plazme, termodinamičke karakteristike i način na koji nastaje. Zahvaljujući svojim karakteristikama plazma se primenjuje kao izvor energije za plazma sprej procese (APS i VPS), koji se koriste za zaštitu površina osnovnog materijala od habanja, abrazije, erozije, kavitacije, korozije i otpornosti na zamor na niskim i povišenim temperaturama uz povećani resurs i pouzdanost rada delova u eksploataciji.

\section{Struktura plazme i njene termodinamičke karakteristike}

Da bi se razumeo plazma sprej proces, potrebno je, pre svega, poznavati strukturu plazme. Naučnici su naziv plazma koristili da bi opisali pare materijala koje se podižu na viši energetski nivo. Zagrejani gasovi slede klasične zakone fizike i termodinamike. Međutim, plazma ne sledi klasične zakone fizike i zbog toga se smatra četvrtim agregatnim stanjem materije. Da bi se objasnila plazma, moraju se pojasniti promene stanja koje se dešavaju u atomima i molekulima. Jedan neutralan atom He ima jezgro sa dva električna naboja i neutralan je kada se nalazi u nepobuđenom stanju. Oko jezgra atoma kruže dva elektrona. Svaki elektron ima -1 električni naboj. Ako se atomu dovede dovoljno energije, ona će pobuditi atom i izbaciti bar jedan elektron iz orbite. Iznos energije potreban da bi se izbacio elektron iz orbite zove se energija jonizacije. Pobuđivanjem atoma dobijaju se dve čestice. Jedna čestica je jonizovani atom, a druga slobodan elektron. Jonizovani atom ima električni naboj +1 , a slobodni elektron električni naboj -1 . Molekul koji je spoj dva ili više neutralnih atoma može se smatrati jednom česticom. Molekuli predstavljaju gasove kao što su $\mathrm{N}_{2}$ i $\mathrm{H}_{2}$, koji su formirani od dva atoma i zato se nazivaju dvoatomski gasovi. Ako je dovedeno dovoljno energije, molekuli se razlažu na atome. Odvojeni atomi mogu predstavljati jednoatomski gas kao što je $\mathrm{Ar}$, He ili disocirani dvoatomski gas $\mathrm{N}_{2}$ ili $\mathrm{H}_{2}$. Daljim dovođenjem energije atomima izbija se bar jedan elektron iz svakog atoma. Ako svi elektroni napuste svoje atome dobija se potpuna jonizacija - stanje zvezda sa približnom temperaturom od 100 miliona ${ }^{\circ} \mathrm{C}$. U procesu plazma spreja radi se sa delimičnom jonizacijom i temperaturama do $30.000^{\circ} \mathrm{C}$. Treba naznačiti da je plazma kao celina elektroneutralna, pošto ima isti broj plus i minus električnih naboja. Prednost plazme nad običnim gasovima je što 
ima višu temperaturu i bolji prenos toplote. Dvoatomski gasovi sa stanovišta promene entalpije su superiorniji od jednoatomskih gasova. Plazma ima visoku elektroprovodljivost koja je povezana sa veoma visokim temperaturama. Električna provodljivost plazme je u velikom opsegu uslovljena stepenom jonizacije, tj. pokretljivošću elektrona, koja je oko 100 puta veća od jona. Jonizacija može biti parcijalna ili višestepena. Energija jonozacije gasa kreće se od 10 do $50 \mathrm{eV}$, a disocijacije od 4 do $10 \mathrm{eV}$. Disocijacija i jonizacija gasa odvija se u određenom perio$d u$, a energije jonizacije i disocijacije se rekombinuju, kako je prikazano za gas $N_{2}$.

$$
\begin{array}{ccc} 
& N^{* * *} \leftrightarrow N^{* *} & +e 47.0 \mathrm{eV} \\
\text { Stepeni rekombinacije } & N^{* *} \leftrightarrow N & +e 29.0 \mathrm{eV} \\
\rightarrow & N^{*} \leftrightarrow N & +e 14.5 \mathrm{eV} \\
N+N \leftrightarrow N_{2} & 9.7 \mathrm{eV}
\end{array}
$$

Stepeni jonizacije

Kod jednoatomskih gasova nema disocijacije i rekombinacije, koja se za dvoatomske gasove odvija na nižoj temperaturi. Zbog toga su za istu snagu napajanja mlazevi plazme Ar i He kraći u odnosu na mlazeve plazme $\mathrm{N}_{2}$ i $\mathrm{H}_{2}$. Plazmu je najjednostavnije formirati pomoću gasova $\mathrm{Ar}, \mathrm{He}, \mathrm{H}_{2}, \mathrm{~N}_{2}$ ili njihovih mešavina. Ar ima najveću prednost pošto se lako jonizuje. Entalpije Ar i He su mnogo niže od dvoatomskih gasova, kako je prikazano na slici 5. Sa druge strane, temperature inertnih gasova mnogo su više od $\mathrm{N}_{2}$ i $\mathrm{H}_{2}$ pri istoj entalpiji. Plazma se razlikuje od plamena sagorevanja gasova zbog ćinjenice da se hemijska reakcija sagorevanja gasova javlja na odstojanju od 100 do 200 $\mathrm{mm}$ i ima nižu temperaturu od plazme. Plazma je svetli jonizovani gas kod kojeg ne postoji sagorevanje, a ima visoku temperaturu i brži pad temperature nakon napuštanja mlaznice.

Plazma sprej procesi

Zavisno od okolne sredine, razvijeni su atmosferski plazma sprej - APS i vakuumu plazma sprej - VPS proces za koji se još koristi naziv LPPS (Low preassure plasma deposition). Izbor procesa $u$ velikoj meri određuju osobine deponovanih prevlaka, ali i njihovo ponašanje u eksploataciji, kako je opisano u radovima autora (Mrdak, 2013, pp.725), (Mrdak, 2013, pp.26-47), (Mrdak, 2014, pp.7-22). APS proces je najjednostavniji za izvođenje $i$ ima limitiran opseg upotrebe zbog inkorporiranja znatne količine vazduha u mlaz plazme. Vazduh hladi i usporava plazmu, a poseban problem predstavlja oksidacija čestica, što ima za posledicu povećan sadržaj produkata oksidacije u deponovanom sloju (Mrdak, 2010, pp.5-16), (Mrdak, 2012, pp.182-201), (Vencl, et al., 2010, pp.591-604). Prskanje plazmom vrši se pomoću plazma pištolja iz kojeg izlaze fokusirane čestice plazme inertnog gasa sa brzinom od 240 do $600 \mathrm{~m} / \mathrm{s}$ i temperaturom mlaza od 4.500 do $20.000^{\circ} \mathrm{C}$. Mlaz plazme koji napušta mlaznicu nije homogena sredina, zbog velike razlike u temperaturi i brzini čestica plazme (Vardelle, et al., 1983, 
p.88). Zona jezgra plazme ima relativno konstantnu temperaturu od 12.500 do $12.000^{\circ} \mathrm{C} i$ rasprostire se svega 10 do $12 \mathrm{~mm}$ od otvora mlaznice. Druga zona predstavlja prelaznu oblast u kojoj temperatura plazme naglo opada do $3000^{\circ} \mathrm{C}$ i postiže dužinu oko $100 \mathrm{~mm}$ od otvora mlaznice. Treća zona predstavlja oblast u kojoj dolazi do intenzivnog mešanja plazme sa okolnim vazduhom, što dovodi do pada temperature i pada brzine čestica plazme. Kvalitet deponovanih slojeva zavisi od: karakteristika upotrebljenog praha, međusobne reakcije između plazme i praha, reakcija između plazme i okoline $i$ uticaja podloge. Prahovi koji se koriste za depoziciju karakterišu se hemijskim sastavom, gustinom, temperaturom topljenja, veličinom zrna, raspodelom veličine zrna, oblikom zrna, ponašanjem pri kretanju kroz plazmu, čistoćom itd. Parametri procesa moraju se podesiti tako da se za konkretan prah postigne optimalni efekat topljenja praha u plazmi i transport istopljenih čestica praha sa optimalnim brzinama do površine podloge. Postupak izrade prevlake sastoji se od pripreme površine podloge pre procesa depozicije i procesa depozicije na pripremljenim površinama. Priprema površine podloge jedan je od najvažnijih faktora koji utiče na kvalitet spoja između metalne podloge i deponovane prevlake. Priprema površine izvodi se radi čišćenja oksidnog sloja sa površine metalne podloge, čineći je reaktivnom sa prevlakom i radi povećanja površine između metalne podloge i prevlake. APS proces izvodi se tako što se kroz otvor gas injektora propušta inertni gas Ar između katode $i$ anode. Da bi se inicirala plazma, između elektroda propušta se jednosmerna struja koja stvara električni impuls uzrokujući proboj kroz tekući gas. Uspostavljanjem strujnog luka - lučne plazme, kroz otvor gas injektora propušta se sekundarni gas $\left(\mathrm{He}, \mathrm{H}_{2}\right.$ ili $\mathrm{N}_{2}$ ) koji se jonizuje. Priroda geometrije elektrode kao i tehničkih gasova, sada plazme, istiskuje vruć i delimično provodan gas kroz kružni otvor anode. U tako formiran mlaz plazme uvodi se prah pomoću nosećeg gasa. Čestice praha se ubrzavaju, tope $i$ velikom brzinom deponuju na podlogu. Energija mlaza plazme podešava se za svaku vrstu praha, uzimajući u obzir: temperaturu topljenja, toplotnu provodljivost, oblik, veličinu i raspodelu veličine čestica. Kao dodatak karakteristikama praha postoje i uslovi njegovog injektiranja u mlaz plazme. To su mesta ubrizgavanja praha i ugao u odnosu na smer mlaza i brzine dotoka praha. Protok nosećeg gasa podešava se za svaki tip praha na osnovu srednje veličine čestica praha, njegove gustine i gustine mlaza plazme, tako da su čestice praha ubrizgane $u$ osu mlaza plazme sa najvećom temperaturom. Protok sekundarnog gasa, amperaža, voltaža i odstojanje mlaza plazme podešavaju se za svaki tip praha, tako da čestice koje se deponuju imaju optimalnu kinetičku energiju i stepen istopljenosti.

Razvoj VPS tehnologije doveo je do značajnog poboljšanja kvaliteta prevlaka u poređenju sa prevlakama proizvedenim na atmosferskom pritisku. VPS je relativno nova tehnologija u kojoj se istopljene čestice praha, veličine od 10 do $100 \mu \mathrm{m}$, ubrzavaju ka podlozi, gde se spljošnjavaju i očvršćavaju. VPS prevlake generalno pokazuju veću gustinu od prevlaka deponovanih atmosferskim plazma sprej proce- 
som, čije se lamele sastoje od stubastih zrna. Čestice očvršćavaju veoma velikom brzinom hlađenja od $\sim 10^{4}$ do $10^{8} \mathrm{C} / \mathrm{s}$. Radni vakuum je u rasponu od 30 i 200 mbara, koji omogućava deponovanje prevlaka debljine od 20 do $2 \mathrm{~mm}$. Smanjen pritisak u odnosu na atmosferske uslove povećava dužinu mlaza plazme od 50 do $600 \mathrm{~mm}$ i prečnik od 10 do $40 \mathrm{~mm}$. Brzine i temperature čestica u mlazu plazme su ujednačenije, što omogućava proizvodnju homogenijih prevlaka ujednačene debljine na delovima sa složenim geometrijama (Gindrat, et al., 2002, pp.459-464). Na niskom pritisku temperatura mlaza plazme postepeno opada i u funkciji je pritiska. Za isto odstojanje od otvora mlaznice manji je pad temperature što je pritisak niži. VPS proces izvodi se na niskom pritisku Ar u veoma čistim uslovima i uz primenu transferovanog luka za čišćenje i predgrevanje podloge. Kao plazma gasovi mogu se koristiti: $\mathrm{Ar}, \mathrm{He}, \mathrm{H}_{2}, \mathrm{~N}_{2}$ i mešavine gasova visoke čistoće. Depozicija praha najčešće se izvodi sa mešavinom plazma gasova $\mathrm{Ar}-\mathrm{H}_{2}$ na niskom pritisku u vakuumu. U vakuum-komori nalazi se: obrtni sto, planetarni sistem sa 48 alata, šestoosni robot i veštačka ruka. Sistem manipulacije projektovan je tako da istovremeno rotiraju alat i radni delovi oko svoje ose. Ovako složeno kretanje omogućava ravnomerno čišćenje transferovanim lukom i ravnomerno deponovanje praha po celoj površini podloge. Svi postupci kao delovi ciklusa VPS procesa površinske zaštite moraju se izvršiti što je moguće brže. Da bi se postiglo brzo vakuumiranje komore potreban je visok kapacitet pumpanja. Za postizanje pritiska u komori od 1000 do 0,1 bar potrebno je vreme od 5 min. Unošenje i iznošenje radnih komada treba da se obavlja što je moguće brže nakon ventilacije komore. Sve unutrašnje površine vakuum- komore postaju zaštićene plazma gasovima za vreme procesa VPS zaštite. Jedino se atomi neutralnog gasa vezuju za površine komore usled Vander-Valsovih sila, što znači da se nakon unošenja i iznošenja radnih komada može uštedeti na vremenu vakumiranja komore. Izbor plazma gasa, brzina toka i struja luka određuju sadržaj energije mlaza plazme. Karakteristike mlaza plazme unutar i izvan pištolja su pod uticajem pritiska u komori. Kako pritisak opada mlaz plazme postaje duži, srazmerno povećanju brzine gasa. Pritisak u komori mora se održavati konstantnim za vreme depozicije. Depozicija na niskom pritisku od 30 do 70 mbara omogućava primenu transferovanog luka i veće brzine čestica plazme. Sa transferovanim lukom omogućeno je čišćenje površine podloge i njeno predgrevanje pre depozicije praha, kao i dodatno zagrevanje u toku depozicije. Mogu se koristiti različiti nivoi pritisaka za transferovani luk, zavisno od karakteristika osnovnog materijala i praha. Da bi se formirao mlaz plazme optimalanih karakteristika, protok gasa može da varira između $1,5 i 20 \mathrm{~m}^{3}$, zavisno od vrste praha koji se deponuje. Depozicija prevlake na podlogama izvodi se na sledeći način: radni delovi se montiraju u noseće alate koji se nalaze na planetarnom sistemu koji se okreće oko svoje ose, a nakon montaže radnih delova vakuum-komora se zatvara. Ceo sistem je automatizovan i programiran na mikroprocesorskoj jedinici robota. U program se ubacuju 
svi parametri procesa. Proces vakuumiranja komore, protok plazma gasova, čišćenje substrata, protok praha, depozicija, hlađenje substrata $i$ ventilacija vakuum-komore potpuno su vremenski sinhronizovani programom. U VPS - komori, veštačka ruka koja se nalazi na drugoj strani otvora komore, i ne vidi se na slici, prihvata alat sa radnim delom sa planetarnog sistema i postavlja ga na obrtni sto. Nakon montaže alata sa radnim delom vrši se vakuumiranje komore u kojoj se za 5 min postiže pritisak od $10^{-3}$ mbara. Kada se završi proces vakumiranja, u komoru se kroz anodu ubacuje Ar do nivoa pritiska od 25 mbara. Na ovom pritisku izvodi se čišćenje površina radnih delova transferovanim lukom. Odstojanje plazma pištolja od površine radnih delova najčešće je $270 \mathrm{~mm}$. Plazma pištolj se u procesu čišćenja površine postavlja na + pol, a radni deo na - pol. Ova veza se zove ditrektni polaritet i omogućava usmerenim jonima sekundarnog gasa He da velikom brzinom $i$ energijom očiste površinu radnog dela od nečistoće, čineći površinu reaktivnom. Nakon izvršenog čišćenja površine radnog dela izvodi se deponovanje praha na površini dela. Primarnom gasu Ar dodaje se plazma sekundarni gas $\mathrm{H}_{2}$. Pritisak u komori raste do nivoa radnog pritiska od 70 do120 mbara, zavisno od vrste praha koji se deponuje. Konstantan pritisak u toku depozicije obezbeđuje vakuum-pumpa. Kada se postigne radni pritisak, u plazma pištolj se ubacuje prah. Brzina depozicije je konstantna i ne menja se u toku depozicije. Za približno jedan minut deponuje se sloj prevlake od $0,1 \mathrm{~mm}$. Kada se završi proces depozicije, radni deo se hladi u komori do temperature od $300^{\circ} \mathrm{C}$ sa argonom koji teče iz otvora anode plazma pištolja F4. Ohlađen radni deo sa alatom prihvata veštačka ruka i vraća na svoje prvobitno mesto. Planetarni sistem se zaokreće za jedan korak, kako bi veštačka ruka prihvatila drugi alat sa radnim delom. Ciklus depozicije praha se ponavlja, dok se na svim radnim delovima ne izvede depozicija praha.

\section{Zaključak}

$U$ radu je opisana struktura plazme, način njenog stvaranja $i$ termodinamičke karakteristike: entalpija, temperatura, specifične toplote $i$ toplotne provodljivosti gasova, kao i plazma sprej procesi na atmosferskom pritisku i u vakuumu na niskom pritisku inertnog gasa. Plazma sprej procesi razvijeni su za depoziciju istopljenih ili poluistopljenih čestica praha na površinu osnovog materijala na kojoj deponovane čestice formiraju prevlake.

Prednost plazma sprej procesa je mogućnost primene velikoga broja različitih materijala $u$ obliku praha različite granulacije i morfologije, koji su pogodni za formiranje prevlaka radi zaštite površine osnovnog materijala od habanja, abrazije, erozije, kavitacije, korozije i otpornosti na zamor na niskim i povišenim temperaturama. Plazma sprej procesi takođe omogućuju modifikaciju prahova, kao što je sferoidizacija prahova sa oštrim ivicama, zgušnjavanje poroznih čestica, a u novije vreme i formiranje nanoprahova. Prednost procesa je što istopljene 
čestice praha sa visokom tačkom topljenja ne prenose veliku količinu toplote u osnovni materijal i ne narušavaju strukturu osnovnog materijala. U procesu depozicije najbitnije je kontrolisati prenos toplote sa prevlake na podlogu, koji je u funkciji sastava plazma gasa, snage napajanja i vremena boravka čestica u mlaz plazme.

APS i VPS plazma sprej procesi imaju široku primenu u proizvodnji novih delova radi zaštite radnih površina i reparacije pohabanih delova u procesu remonta primenom adekvatnih prevlaka koje znatno poboljšavaju funkcionalnost i povećavaju radni vek delovima.

Ključne reči: otpornost, prahovi, plazma gas, provodljivost, prevlake.

Datum prijema članka / Paper received on / Дата получения работы: 03. 11. 2014.

Datum dostavljanja ispravki rukopisa / Manuscript corrections submitted on / Дата получения исправленной версии работы: 09. 11. 2014.

Datum konačnog prihvatanja članka za objavljivanje / Paper accepted for publishing on / Дата окончательного согласования работы: 11. 11. 2014. 